\title{
ANALISIS PENERAPAN SISTEM K3 TERHADAP KINERJA PROYEK JALAN TOL CIJAGO SEKSI 2B
}

\author{
Yunika $^{1}$ 凹, Haryono Putro ${ }^{2}$ \\ ${ }^{1.2}$ Universitas Gunadarma, Teknik Sipil, Jl. Margonda Raya, No. 100, Pondok Cina, Depok, Jawa Barat \\ 16424 \\ e-mail: yunika.yunika0106@gmail.com
}

\begin{abstract}
Recognizing the importance of occupational safety and health (K3) in order to provide a sense of security and prevent work accidents so as to increase morale or performance of other workers. The study discusses the effect of the application of occupational safety and health $(\mathrm{K} 3)$ on the performance of construction project workers. Companies are requested to immediately apply the new Occupational Safety and Health (K3) standards as stated in the Minister of Manpower Regulation (Permenaker) No.5 of 2018 concerning K3. Employers and Management who do not meet the provisions in this Ministerial Regulation are subject to sanctions in accordance with the Law Number 1 of 1970 concerning Work Safety and Law Number 13 of 2003 concerning Employment. On this occasion the researchers used quantitative methods and the research was conducted at the Cijago Depok toll road during working hours. The average weighting value is $84 \%$, so it can be said that the application of the safety management system and occupational health (SMK3) on the Cijago toll road section 2 B project has been running quite well and effectively. However, in this study, several variables have the lowest score and can affect project performance. Therefore, these variables will be given preventive variables including is variable which has a weight of $<76 \%$, namely: X13 which is a variable with the statement "The company presents the results of measurements of noise, vibration, temperature, dust to ensure the implementation of $\mathrm{K3}$ is going well and correctly" therefore according to expert opinion there is a need for preventive measures. The variable that can affect project performance is the variable that has the highest weighting, X17 regarding "OHS regulations and procedures needed" with a weighting of $89 \%$ means that project performance is influenced by project workers who feel safe if there are $\mathrm{OHS}$ regulations and procedures required that are clearly described and as evidenced by the increase in the $S$ curve
\end{abstract}

Keywords: System K3 , APD , Employment

\begin{abstract}
Abstrak
Menyadari pentingnya keselamatan dan kesehatan kerja (K3) agar dapat memberi rasa aman dan mencegah kecelakaan kerja sehingga dapat meningkatkan semangat ataupun kinerja para pekerja lainnya. Penelitian membahas mengenai pengaruh penerapan keselamatan dan kesehatan kerja (K3) terhadap kinerja pekerja proyek konstruksi. Perusahaan-perusahaan diminta segera menerapkan standar Keselamatan dan Kesehatan Kerja (K3) baru sebagaimana tercantum dalam Peraturan Menteri Ketenagakerjaan (Permenaker) No.5 Tahun 2018 tentang K3.Pengusaha dan Pengurus yang tidak memenuhi ketentuan dalam Peraturan Menteri ini dikenakan sanksi sesuai dengan Undang-Undang Nomor 1 Tahun 1970 tentang Keselamatan Kerja dan Undang-Undang Nomor 13 Tahun 2003 tentang Ketenagakerjaan.Dalam kesempatan kali ini Peneliti menggunakan metode kuantitatif dan penelitiaan dilaksanakan di tol Cijago Depok pada jam kerja Nilai bobot rerata $84 \%$ maka dapat dikatakan bahwa penerapan system Manajeman keselamatan dan kesehatan kerja (SMK3) pada proyek jalan tol cijago seksi 2 B ini telah berjalan Cukup Baik dan Efektif Namun dalam penelitian ini telah didapat beberapa variable yang mempunyai nilai skor terendah dan dapat mempengaruhi kinerja proyek oleh sebab itu variable tersebut akan diberikan tindakan preventive variable yang termasuk adalah variable yang memiliki bobot< 76\% yaitu : X13 dimana adalah variable dengan keterangan "Perusahaan memaparkan hasil pengukuran kebisingan, getaran, suhu, debu untuk memastikan pelaksanaan K3 berjalan dengan baik dan benar” oleh
\end{abstract}


sebab itu berdasarkan pendapat pakar perlu adanya tindakan preventive Sedangkan diketahui ada bobot variable yang dapat mempengaruhi kinerja proyek yaitu variable yang mempunyai bobot paling besar yaitu X17 tentang "Peraturan dan prosedur K3 sangat diperlukan" dengan bobot $89 \%$ artinya kinerja proyek dipengaruhi oleh pekerja proyek yang merasa aman jika ada peraturan dan prosedur K3 yang diperlukan dengan jelas dipaparkan dan terbukti dengan peningkatan di kurva $S$

Kata Kunci : Sistem K3 , APD, Ketenagakerjaan

\section{Pendahuluan}

Keselamatan dan kesehatan kerja (K3) sebagai salah satu aspek perlindungan tenaga kerja memiliki peran yang besar dalam upaya meningkatkan produktivitas perusahaan (Sutjana, 200 6:144). Menurut Mangkunegara (2002:142), keselamatan dan kesehatan kerja adalah suatu pemikiran dan upaya untuk menjamin keutuhan dan kesempurnaan baik jasmaniah maupun rohaniah tenaga kerja pada khususnya dan manusia pada umumnya, hasil karya dan budaya.Untuk menuju masyarakat adil dan makmur. Oleh karena itu diperlukannya sistem manajemen kesehatan dan keselamatan kerja (SMK3) agar angka kecelakaann kerja dapat diminimalisir.

Pendidikan keselamatan dan kesehatan kerja juga berguna agar tenaga kerja memiliki pengetahuan dan kemampuan mencegah kecelakaan kerja, mengembangkan konsep dan kebiasaan pentingnya keselamatan dan kesehatan kerja, memahami ancaman bahaya yang ada di tempat kerja dan menggunakan langkah pencegahan kecelakaan kerja. Masalah keselamatan dan kesehatan kerja (K3) secara umum di Indonesia masih sering terabaikan. Hal ini ditunjukkan dengan masih tingginya angka kecelakaan kerja. Anas Zaini Z Iksan selaku Ketua Umum Asosiasi Ahli Keselamatan dan Kesehatan Kerja (A2K4) mengatakan setiap tahun terjadi
96.000 kasus kecelakaan kerja. Jumlah ini, sebagian besar kecelakaan kerja terjadi pada proyek jasa konstruksi dan sisanya terjadi di sektor industri manufaktur.

Perusahaan-perusahaan diminta segera menerapkan standar Keselamatan dan Kesehatan Kerja (K3) baru sebagaimana tercantum dalam Peraturan Menteri Ketenagakerjaan (Permenaker) No. 5 Tahun 2018 tentang K3.Pengusaha dan Pengurus yang tidak memenuhi ketentuan dalam Peraturan Menteri ini dikenakan sanksi sesuai dengan UndangUndang Nomor 1 Tahun 1970 tentang Keselamatan Kerja dan UndangUndang Nomor 13 Tahun 2003 tentang Ketenagakerjaan.

"Perusahaan-perusahaan di seluruh Indonesia harus mengutamakan aspek perlindungan pekerja dengan menerapkan standar K3 di lingkungan kerja untuk menghindarkan terjadinya kecelakaan kerja dan penyakit akibat kerja," kata Direktur Jenderal Pembinaan Pengawasan Ketenagakerjaan dan K3 (PPK dan K3 ) Sugeng Priyanto.

\section{Tujuan Penelitian}

Adapun tujuan penelitian ini adalah sebagai berikut;

1. Menganalisis penerapan system manajemen keselamatan dan kesehatan kerja (SMK3) pada Proyek Jalan Tol Cijago Seksi 2B 
pada PT. Hutama Karya Infrastruktur di Kota Depok

2. Menganalisis faktor penghambat dan faktor pendorong dalam penerapan sistem manajemen keselamatan dan kesehatan kerja (SMK3) pada Proyek Jalan Tol Cijago Seksi 2B pada PT. Hutama Karya Infrastruktur di Kota Depok

3. Menganalisis tindakan preventive yang dapat dilakukan untuk Variable terendah pada system manajemen keselamatan dan kesehatan kerja (SMK3) pada Proyek Jalan Tol Cijago Seksi 2B pada PT. Hutama Karya Infrastruktur di Kota Depok

\section{Batasan Masalah}

Batasan penulisan dari penelitian ini adalah sebagai berikut :

1. Pengamatan ini dilakukan pada jam kerja efektif (office hours) jam 8- jam 5 sore dengan istirahat satu jam di jam 12

2. Penelitian dilakukan hanya di Kinerja Proyek Jalan Tol Cljago Seksi 2B pada PT. Hutama Karya Infrastruktur di Kota Depok

\section{Kesehatan Kerja}

Kesehatan kerja merupakan suatu hal yang penting dan perlu diperhatikan oleh perusahaan. Karena dengan adanya program kesehatan kerja yang baik akan menguntungkan para karyawan secara material, karena karyawan akan lebih jarang absen dikarenakan sakit akibat tertular teman sekerja atau luar teman sekerja. Bekerja dengan lingkungan yang lebih nyaman dan menyenangkan, sehingga secara keseluruhan karyawan akan mampu bekerja lebih lama dan meningkatkan kinerja lebih baik lagi.

\section{Keselamatan Kerja}

Keselamatan kerja adalah kondisi kerja yang bebas dari resiko kecelakaan dan kerusakan dimana kita bekerja, serta usaha - usaha yang dapat menjamin keadaan dan kesempurnaan pekerja (baik jasmani maupun rohani) beserta hasil karyanya dan alat - alat kerjanya ditempat kerja. Usaha - usaha tersebut haru dilakukan oleh semua unsur - unsur yang terlibat dalam proses kerja yaitu pekerja itu sendiri, pengawas, perusahaan, pemerintah dan masyarakat pada umumnya. Tanpa ada kerjasama yang baik antara semua unsur tersebut mustahil keselamatan kerja dapat diwujudkan secara maksimal (Bambang, 2004)

\section{Manajemen Kesehatan dan Keselamatan Kerja (K3)}

Manajemen kesehatan dan keselamatan kerja tidak terlepas pembahasanmanajemen secara umum karena manajemen kesehatan dan keselamatan kerja merupakan bagian dari manajemen secara keseluruhan. Adapun unsur-unsur manajemen kesehatan dan keselamatan kerja yang terdiri dari manusia material atau bahan-bahan, mesin dan peralatan, dana dan metode secara garis besar dengan prinsip pemecahan masalah yang dianut maka unsur-unsur dapat berupa sumber bahaya apabila tidak memenuhi persyaratan yang diterapakan. Sedangkan menurut Peraturan Menteri Tenaga Kerja No.: PER.05/MEN/ 1996, Sistem Manajemen Kesehatan dan Keselamatan Kerja adalah bagian dari sistem menejemen secara keseluruhan yang meliputi struktur organisasi , perencanaan ,tanggung jawab , pelaksanaan, prosedur, proses dan sumber daya yang dibutuhkan bagi pengembangan , penerapan, pencapaian , pengkajian , pemeliharaan kebijakan keselamatan dan kesehatan kerja dalam 
rangka pengendalian resiko yang bekaitan dengan kegiatan kerja guna terciptanya kerja yang aman , efisien , produktif.Sistem menejemen harus diterapkan di kontraktor yang sistem kerjanya berpotensi mengandung banyak bahaya

\section{Peraturan Kesehatan Dan Keselamatan Kerja (K3)}

Secara umum kecelakaan selalu diartikan sebagai kejadian yang tidak diduga sebelumnya. Sebenarnya, setiap kecelakaan kerja dapat diramalkan atadiduga dari semula jika perbuatan dan kondisi tidak memenuhi persyaratan. Karena itu, kewajiban berbuat secara selamat, dan mengatur peralatan dan perlengkapan produksi sesuai dengan standar yang diwajibkan oleh Undang Undang adalah suatu cara untuk mencegah terjadinya kecelakaan. Undang-Undang Keselamatan Kerja, Lembaga Negara Nomor 1 tahun 1970 adalah UndangUndang Keselamatan Kerja yang berlaku secara nasional diseluruh wilayah hukum Republik Indonesia dan merupakan induk dari seluruh peraturan keselamatan kerja yang berada dibawahnya. Meskipun judulnya disebut Undang-Undang Keselamatan Kerja sesuai dengan bunyi Pasal 18 namun materi yang diatur termasuk masalah kesehatan kerja.

\section{Pengertian Kinerja}

Menurut Prawirosentono (1999) yang dimaksud dengan kinerja adalah hasil kerja yang dapat dicapai oleh seseoran $\mathrm{g}$ atau sekelompok orang dalam suatu organisasi sesuai dengan wewenang dan tanggung jawab masing-masing, dalam rangka pencapaian tujuan organisasi. Kinerja sumber daya manusia (SDM) merupakan istilah yang berasal dari kata job performance (prestasi kerja atau prestasi sesungguhnya yang dicapai seseorang). Menurut Mangkunegara (2002:67) kinerja merupakan hasil kerja secara

kualitas dan kuantitas yang dicapai ole $\mathrm{h}$ seseorang pegawai dalam melaksanakan tugasnya sesuai dengan tanggung jawab yang diberikan kepadanya. Menurut Martoyo (2000:92) kinerja merupakan penampilan kerja seseorang itu sendiri dan taraf potensi seseorang dalam upayanya mengembangkan diri untuk kepentingan perusahaan dan organisasi. Jadi, kinerja merupakan hasil atau output tersebut berasal dari kerja karya wan, maka hal itu dinamakan kinerja karyawan. Dan jika output tersebut berasal dari pengusaha.

\section{Metode Penelitian}

Metode pengumpulan data yang digunakan adalah kuantitatif untuk mengetahui standar sistem keselamatan dan kesehatan kerja (K3) pada proyek tersebut yang sudah diterapkan dan dilaksanakan kontraktor untuk kinerja proyek.

\section{Penyebaran Kuesioner}

Penyebaran kuisioner disebarkan kepada responden yang terdiri dari tim kontraktor, tenaga kerja, konsultan pengawas serta tim K3\&LH PT Hutama Karya. Dimana struktur kuesioner terbagi dalam tiga bagian :

a) Profil responden Berisi mengenai informasi identitas responden yaitu nama, pendidikan terakhir, umur, dan jabatan (spesifikasi pekerjaan).

b) Petunjuk Pengisian Kuesioner Pada bagian ini, responden diberi petunjuk pengisian kuesioner, sehingga responden tidak salah 
dalam pengisian jawaban kuesioner.

c) Kuesioner Pertanyaan yang digunakan adalah jenis pertanyaan tertutup untuk mempermudah responden menjawab pertanyaan dan memfokuskan jawaban yang diharapkan penulis.

\section{Sampel Penelitian}

Sampel penelitian ini adalah staff dan pekerja pada kontraktor utama yang ikut berpartisipasi dalam pengisian kuesioner untuk responden. Kuesioner untuk responden tersebut disebar pada survey di bulan November 2017 sampai dengan bulan Januari 2018, dengan banyaknya responden sebesar 39 orang.

\section{Lokasi dan Waktu Penelitian}

a. Lokasi Penelitian

Lokasi penelitian bertempat pada Proyek jalan Tol Cijago Seksi 2B

b. Waktu Penelitian

Penelitian ini dilakukan pada Office Hour ( Pukul 08:00 - Pukul 17:00) dengan 1 jam istirahat (jam 12)

\section{Lokasi Penelitian}

Jalan Tol Cijago (Cinere - Jagorawi) seksi 2B merupakan bagian dari Jakarta Outer Ring Road II (JORR II) yang mana Jalan Tol ini menghubungkan Jalan Tol Cijago Seksi 2A dengan Jalan Tol Cijago Seksi 3. Pembangunan Jalan Tol ini dimaksudkan untuk mewujudkan pemerataan pembangunan dan pengembangan wilayah serta untuk meningkatkan efisiensi pelayanan jasa transportasi dan distribusi guna menunjang pertumbuhan ekonomi. Lokasi proyek Jalan Tol Cijago Seksi 2B terletak antara Jl. Margonda Raya dengan Jl. Kukusan Raya, Kota Depok

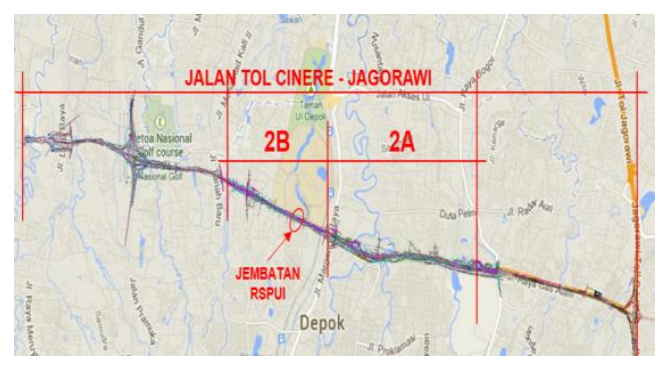

Gambar 1. Peta Jalan Tol Cinere-Jagorawi

Metode yang digunakan untuk mengukur analisis penerapan SMK3 proyek terhadap pelaksanaan proyek yaitu dengan mengunakan metode pembobotan atau scoring. Skor adalah hasil pekerjaan menyekor (memberikan angka) yang diperoleh dari angka-angka dari setiap pertanyaan yang telah dijawab olehresponden dengan benar, dengan mempertimbangkan bobot (Jula Nujhani, 2013). Adapun analisis data menggunakan Skala Likert. Pertanyaan pada kuesioner yang disebarkan menjadi indikator dalam menentukan tingkat keberhasilan penerapan sistem manajemen keselamatan dan kesehatan kerja (SMK3).

Hasil penilaian kuesioner dari responden yang telah dibuatkan tabulasi data, selanjutnya dihitung dengan menggunakan rumus sebagai berikut (Bayu, widhiawati, andyana, 2015)

Skor $=$ Total Skor (A)Nilai Total B X 100 $\%$

Dimana :

Total Skor $(\mathrm{A})=$ Total nilai skor $1-5$

Nilai Total $(B)=$ Total Nilai Skor Maksimum

Dalam penelitian ini sistem skor yang digunakan adalah sebagai berikut :

1. Skor 1 STS (Sangat Tidak Setuju) 


\section{Skor 2 TS (Tidak Setuju) \\ 3. Skor $3 \mathrm{~N}$ (Netral) \\ 4. Skor 4 ST (Setuju) \\ 5. Skor 5 SS (Sangat Setuju)}

Dari hasil nilai skor yang didapat, maka hasil kesimpulan sebagai berikut :

a. SS : Sangat Setuju diberi skor 5 (Persentase $81 \%$ sampai dengan $100 \%)$

b. ST : Setuju diberi skor 4 (Persentase $61 \%$ sampai dengan kurang dari $\leq$ $80 \%)$

c. RG : Ragu-ragu diberi skor 3 (Persentase $41 \%$ sampai dengan kurang dari $\leq 60 \%$ )

d. TS : Tidak setuju diberi skor 2 (Persentase $21 \%$ sampai dengan kurang dari $\leq 40 \%$ )

e. STS : Sangat tidak setuju diberi skor 1 (Persentase kurang dari $\leq 20 \%$ )

Hasil akhir yang diperoleh dikelompokkan berdasarkan range yang telah ditentukan. Hasil akhir merupakan angka dari keefektifan penerapan sistem manajemen keselamatan dan kesehatan kerja (SMK3) terhadap pelaksanaan proyek peningkatan kapasitas landasan terbang Bandar Udara Soekarno-Hatta. Adapun tabel klasifikasi keberhasilan SMK3, sebagai berikut :

Tabel 1. Klasifikasi Keberhasilan SMK3 dengan metode Scoring

\begin{tabular}{|r|r|}
\hline Range Nilai Total & Keterangan \\
\hline $\mathrm{X} \geq 95$ & $\begin{array}{r}\text { SMK3 Proyek berhasil } \\
\text { dengan sangat baik dan } \\
\text { efektif }\end{array}$ \\
\hline $75 \leq \mathrm{X} \leq 95$ & $\begin{array}{r}\text { SMK3 Proyek } \\
\text { Cukup baik dan efektif }\end{array}$ \\
\hline $50 \leq \mathrm{X} \leq 75$ & SMK3 Proyek kurang baik \\
\hline
\end{tabular}

\begin{tabular}{|r|r|}
\hline $\mathrm{X} \leq 50$ & $\begin{array}{r}\text { SMK3 Proyek Belum } \\
\text { berhasil/gagal }\end{array}$ \\
\hline
\end{tabular}

Sumber : Klasifikasi metode pembobotan (scoring) (Jula Nujhani 2013)

Penilaian interpretasi responden terhadap item pertanyaan kuesioner adalah hasil nilai yang dihasilkan dengan menggunakan rumus index $\%$, sebagai berikut :

\section{Rumus Index $\%=$ Total Skor Nilai Tertinggi X $100 \%$}

Sedangkan Rumus yang dipakai untuk menentukan jumlah responden adalah rumus slovin. Rumus Slovin adalah sebuah rumus atau formula untuk menghitung jumlah sampel minimal apabila perilaku dari sebuah populasi tidak diketahui secara pasti. Rumus ini pertama kali diperkenalkan oleh Slovin pada tahun 1960. Rumus slovin ini biasa digunakan dalam penelitian survey dimana biasanya jumlah sampel besar sekali, sehingga diperlukan sebuah formula untuk mendapatkan sampel yang sedikit tetapi dapat mewakili keseluruhan populasi.

$$
\mathrm{n}=\mathrm{N} /\left(1+\left(\mathrm{N} \mathrm{x} \mathrm{e} \mathrm{e}^{2}\right)\right)
$$

Dari notasi diatas, $\mathrm{n}$ adalah jumlah sampel minimal, nilai $\mathrm{N}$ adalah populasi sedangkan nilai e adalah error margin.

Berangkat dari ide perihal margin error inilah mungkin sang pencipta dari rumus ini memberikan kesempatan kepada para peneliti untuk menetapkan besar sampel minimal berdasarkan tingkat kesalahan atau margin of error.

Misalnya sebuah penelitian dengan derajat kepercayaan 95\%, maka tingkat kesalahan adalah 5\%. Sehingga peneliti dapat menentukan batas minimal sampel yang 
dapat memenuhi syarat margin of error 5\% dengan memasukkan margin error tersebut ke dalam formula atau rumus slovin.

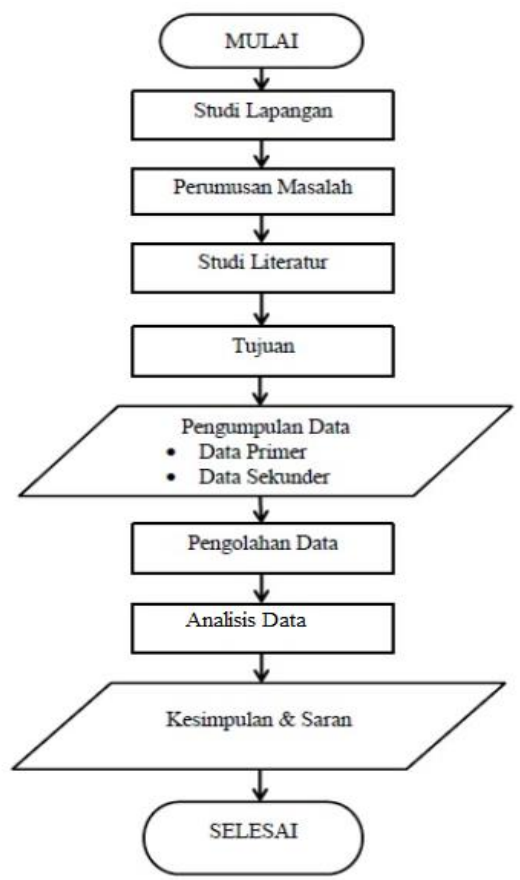

Gambar 2. Alur Metode Penelitian

\section{Hasil dan Pembahasan}

\section{Penerapan Keselamatan dan Kesehatan Kerja}

Tabel 2. Presentase Bobot Variabel Penerapan Keselamatan dan Kesehatan Kerja

\begin{tabular}{|c|c|c|c|}
\hline NO & VARIABEL & SKOR & BOBOT \\
\hline 1 & X1 & 155 & $86 \%$ \\
\hline 2 & $\mathrm{X} 2$ & 156 & $87 \%$ \\
\hline 3 & $\mathrm{X} 3$ & 145 & $81 \%$ \\
\hline 4 & $\mathrm{X} 4$ & 151 & $84 \%$ \\
\hline 5 & $\mathrm{X} 5$ & 153 & $85 \%$ \\
\hline 6 & $\mathrm{X} 6$ & 150 & $83 \%$ \\
\hline 7 & $\mathrm{X} 7$ & 148 & $82 \%$ \\
\hline 8 & $\mathrm{X} 8$ & 146 & $81 \%$ \\
\hline 9 & $\mathrm{X} 9$ & 146 & $81 \%$ \\
\hline 10 & $\mathrm{X} 10$ & 148 & $82 \%$ \\
\hline 11 & $\mathrm{X} 11$ & 141 & $78 \%$ \\
\hline 12 & $\mathrm{X} 12$ & 152 & $84 \%$ \\
\hline 13 & $\mathrm{X} 13$ & 135 & $75 \%$ \\
\hline 14 & $\mathrm{X} 14$ & 143 & $79 \%$ \\
\hline 15 & $\mathrm{X} 15$ & 145 & $81 \%$ \\
\hline 16 & $\mathrm{X} 16$ & 139 & $77 \%$ \\
\hline & $\mathrm{RATA}-$ & & $82 \%$ \\
\hline & $\mathrm{RATA}$ & & \\
\hline
\end{tabular}

Karena nilai bobot mempunyai skor $82 \%$, maka dapat dikatakan bahwa responden sangat setuju dengan penerapan keselamatan dan kesehatan kerja di proyek jalan tol Cijago seksi 2B

\section{Peraturan dan prosedur keselamatan dan kesehatan kerja}

Tabel 3. Presentase Bobot Variabel Peraturan dan Prosedur Keselamatan dan kesehatan kerja

\begin{tabular}{|r|c|c|c|}
\hline NO & VARIABEL & SKOR & BOBOT \\
\hline 17 & X17 & 161 & $89 \%$ \\
\hline 18 & X18 & 152 & $84 \%$ \\
\hline 19 & X19 & 140 & $78 \%$ \\
\hline 20 & X20 & 145 & $81 \%$ \\
\hline 21 & X21 & 140 & $78 \%$ \\
\hline 22 & X22 & 151 & $84 \%$ \\
\hline 23 & X23 & 155 & $86 \%$ \\
\hline & RATA- & & $83 \%$ \\
& RATA & & \\
\hline
\end{tabular}

Hasil dari rata rata bobot iterpretasi Peraturan dan prosedur Keselamatan dan kesehatan kerja sebesar $83 \%$ menunjukan bahwa Kontraktor Hutama Karya sudah dapat menerapkapn peraturan dan prosedur keselamatan dengan baik dan sesuai

\section{Komitmen Management terhadap kesehatan dan keselamatan kerja}

Tabel 4. Presentase Bobot Variabel Komitmen Managemen terhadap kesehatan dan keselamatan

\begin{tabular}{|c|c|c|c|}
\hline NO & VARIABEL & SKOR & BOBOT \\
\hline 24 & X24 & 155 & $86 \%$ \\
\hline 25 & X25 & 150 & $83 \%$ \\
\hline 26 & X26 & 151 & $84 \%$ \\
\hline 27 & X27 & 151 & $84 \%$ \\
\hline & $\begin{array}{c}\text { RATA- } \\
\text { RATA }\end{array}$ & & $84 \%$ \\
\hline
\end{tabular}

Hasil bobot $84 \%$ menunjukan bahwa komitment yang dijalankan perusahaan sangat baik dan responden menyetujui hal tersebut

\section{Lingkungan Kerja}


Tabel 5. Presentase Bobot Variabel Lingkungan Kerja

\begin{tabular}{|c|c|c|c|}
\hline NO & VARIABEL & SKOR & BOBOT \\
\hline 42 & X42 & 157 & $87 \%$ \\
\hline 43 & $X 43$ & 154 & $86 \%$ \\
\hline 44 & X44 & 161 & $89 \%$ \\
\hline 45 & X45 & 154 & $86 \%$ \\
\hline & RATA- & & $87 \%$ \\
& RATA & & \\
\hline
\end{tabular}

Lingkungan kerja yang tercipta juga dapat dikatakan lingkungan kerja yang nyaman dan membuat para pekerja atau responden bisa bekerja dengan baik dengan dukungan tempat kerja yang baik ini terbuktu dari hasil pembobotan sebesar $85 \%$

\section{Keterlibatan Pekerja}

Tabel 6. Presentase Bobot Variabel Lingkungan Kerja

\begin{tabular}{|c|c|c|c|}
\hline NO & VARIABEL & SKOR & BOBOT \\
\hline 35 & X35 & 142 & $79 \%$ \\
\hline 36 & X36 & 159 & $88 \%$ \\
\hline 37 & X37 & 155 & $86 \%$ \\
\hline 38 & X38 & 152 & $84 \%$ \\
\hline 39 & X39 & 139 & $77 \%$ \\
\hline 40 & X40 & 145 & $81 \%$ \\
\hline 41 & X41 & 142 & $79 \%$ \\
\hline & $\begin{array}{c}\text { RATA- } \\
\text { RATA }\end{array}$ & & $82 \%$ \\
\hline
\end{tabular}

Untuk keterlibatan pekerja dinilai cukup baik dan terbukti bahwa proyek ini dapat bekerjasama dengan baik dengan pekerja dengan hasil bobot $82 \%$

\section{Evaluasi keselamatan dan kesehatan kerja}

Tabel 7. Presentase Bobot Variabel Evaluasi dan Kesehatan Kerja

\begin{tabular}{|c|c|c|c|}
\hline NO & VARIABEL & SKOR & BOBOT \\
\hline 28 & X28 & 161 & $89 \%$ \\
\hline 29 & $\mathrm{X} 29$ & 149 & $83 \%$ \\
\hline 30 & $\mathrm{X} 30$ & 149 & $83 \%$ \\
\hline 31 & $\mathrm{X} 31$ & 158 & $88 \%$ \\
\hline 32 & $\mathrm{X} 32$ & 150 & $83 \%$ \\
\hline 33 & $\mathrm{X} 33$ & 149 & $83 \%$ \\
\hline 34 & $\mathrm{X} 34$ & 153 & $85 \%$ \\
\hline & $\begin{array}{c}\text { RATA- } \\
\text { RATA }\end{array}$ & & $85 \%$ \\
\hline
\end{tabular}

Hasil bobot yang mencapai $87 \%$ menunjukan bahwa pihak perusahaan cukup serius dalam evaluasi Kesehatan dan keselamatan kerja di proyek

\section{Hasil Penerapan Sistem Manajemen Keselamatan dan Kesehatan Kerja (SMK3}

Rekapitulasi hasil Analisis penerapan system Manajemen Keselamatan dan Kesehatan Kerja pada proyek Jalan tol Cijago Seksi 2 B adalah sbb :

Tabel 8. Tabel Presentase Bobot Variabel

\begin{tabular}{|c|c|c|}
\hline NO & VARIABEL & BOBOT \\
\hline 1 & Penerapan Keselamatan dan kesehatan kerja & $82 \%$ \\
\hline 2 & $\begin{array}{c}\text { Peraturan dan Prosedur keelamatan dan } \\
\text { kesehatan kerja }\end{array}$ & $83 \%$ \\
\hline 3 & $\begin{array}{c}\text { Komitmen Management terhadap kesehatan } \\
\text { dan keselamatan kerja }\end{array}$ & $84 \%$ \\
\hline 4 & Lingkungan Kerja & $85 \%$ \\
\hline 5 & Keterlibatan Pekerja & $82 \%$ \\
\hline 6 & Evaluasi Keselamatan dan Kesehatan Kerja & $87 \%$ \\
\hline & Rata-Rata & $84 \%$ \\
\hline
\end{tabular}

Dengan nilai bobot rerata $84 \%$ maka dapat dikatakan bahwa penerapan system Manajeman keselamatan dan kesehatan kerja (SMK3) pada proyek jalan tol cijago seksi 2 B ini telah berjalan Cukup Baik dan Efektif Berdasarkan hasil tersebut diketahui bahwa penerapan system K3 yang baik ini dapat meningkatkan kinerja proyek.

Namun dalam penelitian ini telah didapat beberapa variable yang mempunyai nilai skor terendah dan dapat mempengaruhi kinerja proyek oleh sebab itu variable tersebut akan diberikan tindakan 
preventive variable yang termasuk adalah variable yang memiliki bobot $>76 \%$ yaitu : X13 dimana adalah variable dengan keterangan "Perusahaan memaparkan hasil pengukuran kebisingan, getaran, suhu, debu untuk memastikan pelaksanaan K3 berjalan dengan baik dan benar" oleh sebab itu berdasarkan pendapat pakar perlu adanya tindakan preventive berupa :

1. Hasil test dibuat dalam bahasa yang mudah dimengerti sehingga bisa dimengerti oleh pekerja

2. Perlu adanya sosialisasi mengenai hal ini

3. Adanya pengawasan dan himbauan mengenai variable ini

Sedangkan diketahui ada bobot variable yang dapat mempengaruhi kinerja proyek yaitu variable yang mempunyai bobot paling besar yaitu X17 tentang "Peraturan dan prosedur K3 sangat diperlukan" dengan bobot $89 \%$ artinya kinerja proyek yang dipengaruhi oleh pekerja proyek yang merasa aman jika ada peraturan dan prosedur K3 yang diperlukan dengan jelas dipaparkan . Menurut pendapat beberapa pakar diketahui bahwa kinerja proyek ini dipengaruhi oleh penerapan SMK3

a. Penerapan Keselamatan dan Kesehatan Kerja untuk variable penerapan keselamatan dan kesehatan kerja dengan dihimbau melalui safety talk dan koordinasi melalui kepala per divisi untuk dikomunikasikan dengan anggotanya secara jelas.

b. Peraturan dan prosedur keselamatan dan kesehatan kerja.

Untuk Variable Peraturan dan Prosedur keselamatan dan kesehatan kerja , tentu menggunakan OHSAS, ISO, dan SMK3 yang berlaku di negara c. Lingkungan kerja

Menciptakan lingkungan kerja yang aman dan nyaman

d. Keterlibatan pekerja Melibatkan para pekerja untuk bisa aktif dalam setiap kegiatan

e. Evaluasi Keselamatan dan kesehatan kerja melakukan evaluasi kerja per 3 bulan bersama para HSE dari berbagai cabang. Melihat kurva S yang ada

\section{KESIMPULAN DAN SARAN}

\section{Kesimpulan}

1. Nilai bobot rerata $84 \%$ maka dapat dikatakan bahwa penerapan system Manajeman keselamatan dan kesehatan kerja (SMK3) pada proyek jalan tol cijago seksi $2 \mathrm{~B}$ ini telah berjalan Cukup Baik dan Efektif.

2. Namun dalam penelitian ini telah didapat beberapa variable yang mempunyai nilai skor terendah dan dapat mempengaruhi kinerja proyek oleh sebab itu variable tersebut akan diberikan tindakan preventive variable yang termasuk adalah variable yang memiliki bobot $<76 \%$ yaitu : X13 dimana adalah variable dengan keterangan "Perusahaan memaparkan hasil pengukuran kebisingan, getaran, suhu, debu untuk memastikan pelaksanaan K3 berjalan dengan baik dan benar" oleh sebab itu berdasarkan pendapat pakar perlu adanya tindakan preventive

3. Sedangkan diketahui ada bobot variable yang dapat mempengaruhi kinerja proyek yaitu variable yang mempunyai 
bobot paling besar yaitu X17 tentang "Peraturan dan prosedur K3 sangat diperlukan" dengan bobot $89 \%$ artinya kinerja proyek dipengaruhi oleh pekerja proyek yang merasa aman jika ada peraturan dan prosedur K3 yang diperlukan dengan jelas dipaparkan dan terbukti dengan peningkatan di kurva $S$

\section{Saran}

1. Penelitian analisis penerapan system management $\mathrm{K} 3$ yang dilakukan hanya terbatas pada pelaksanaan proyek jalan tol Cijago Seksi 2B, sehingga untuk penelitian kedepannya bisa diterapkan di gedung dan jembatan serta bendungan

2. Pelaksanaan SMK3 ini harus lebih diperhatikan guna memperbaiki kinerja proyek

\section{Daftar Pustaka}

[1] Ali, F. 2008. Tinjauan Penerapan K3 pada Proyek Pembangunan Gedung Badan Perpustakaan dan Arsip Propinsi Riau. Skripsi Teknik Sipil. Pekanbaru: Universitas Riau.

[2] Ariza E.N, Sugiyarto, Fajar Sri H., 2016. Analisis Pengaruh Kesehatan dan Keselamatan Kerja (K3) Terhadap Kinerja Pekerja Konstruksi pada Proyek Pembangunan Fly Over Palur. e.Jurnal Matriks Teknik Sipil, Fakultas Teknik, Program Studi Teknik Sipil Universitas Sebelas Maret, Surakarta.

[3] Bambang Endroyo, Tugino., 2009. Analisis Faktor-Faktor Penyebab Kecelakaan Kerja Konstruksi. Jurnal Ilmiah Teknik Sipil dan Perencanaan, Nomor 1 Volume 9-Januari 2007, Hal 2131. Fakultas Teknik, Jurusan Teknik Sipil, Universitas Negeri Semarang (UNNES).
[4] Christina, Wieke Yuni, dkk. Pengarug Budaya Keselamatan dan Kesehatan Kerja (K3) Ternadap Kinerja Proyek Konstruksi. Jurnal : Teknik Sipil Universitas Brawijaya (Rekayasa Sipil) Volume 6, No. 1 - 2012 ISSN 1978 - 5658

[5] Endroyo,B.2006. Peranan Manajemen K3 dalam Pencegahan Kecelakaan Kerja Konstruksi. Jurusan Teknik Sipil, Fakultas Universitas Negeri Semarang.

[6] Febyana Pangkey.,2012. Penerapan System Manajemen Keselamatan dan Kesehatan Kerja (SMK3) pada proyek konstruksi di Indonesia. (Studi Kasus: Pembangunan Jembatan Dr.Ir.SoekarnoManado). Jurnal Ilmiah Media Enggineering, Vol.2, No.2, Juli. Fakultas Teknik, Jurusan Teknik Sipil, Uniiversitas Sam Ratungali.

[7] Ferry Nurja. 2016. Evaluasi penerapan system manajemen keselamatan dan kesehatan kerja (SMK3) pada proyek peningkatan kapasitas landasan terbang. Skripsi. Jurusan Teknik Sipil, Sekolah Tinggi Teknik PLN.

[8] Indria, S. 2009. Program Keselamatan dan Kesehatan Kerja sebagai wujud dari kebijakan K3 di PT. Indocement Tunggal Prakarsa, Tbk. Fakultas Kedokteran Universitas Sebelas Maret Surakarta.

[9] Irwin, H. 2012. Tinjauan Penerapan Sistem Manajemen

Keselamatan dan Kesehatan Kerja pada Pembangunan Menara Dang Merdu Bank Riau Kepri dan Pembangunan The Peak Hotel and Apartment di Pekanbaru. Skripsi Teknik Sipil. Pekanbaru: Universitas Riau.

[10] Lestaril, T. Erlin Trisyulianti (2010). Hubungan Keselamatan dan Kesehatan (K3) dengan Produktivitas Kerja Karyawan (Studi Kasus: Bagian Pengolahan PTPN VIII Gunung Mas, Bogor). Jurnal : IPB. 
[11] Nadya Safira.,2014. Analisa fakor yang mempengaruhi pada kinerja proyek pada pembanguna hotel Batiqa Palembang. Skripsi. Jurusan Teknik Sipil, Universitas Sriwijaya. Sumatera Selatan.

[12] Rukhviyanti, N (2007). Pengaruh penerapan manajemen keselamatan dan kesehatan kerja (K3) terhadap kiinerja karyawan melalui motivasi pada perusahaan Garmen di kawasan industry Rancaekek. Jurnal. Bandung : STIE Indonesia Mandiri. Tanggal akses : 20 Mei 2010.

[13] Suci Restu Miswati Jusan, Hendra Taufik 2016. Tinjauan Penerapan Sistem Manajemen Keselamatan dan Kesehatan Kerja . e.Jurnal Matriks Teknik Sipil, Fakultas Teknik, Universitas Riau, Pekanbaru

[14] Syahrizal, Rahim Matondang.Chairul Muluk , 2015. Analisis Strategi Penanggulangan Kecelakaan Kerja untuk mencapai tingkat kecelakaan kerja nihil Fakultas Teknik, Jurusan Teknik Sipil, UniversitasSumatera Utara.

[15] Wieke Yuni Christina, Ludfi Djakfar, Armanu Thoyib 2012PENGARUH BUDAYA KESELAMATAN DAN KESEHATAN KERJA (K3) TERHADAP KINERJA PROYEK KONSTRUKSI Jurusan Teknik Sipil, Fakultas Teknik Universitas Brawijaya Malang . 